\title{
HIGH PERFORMANCE LIQUID CHROMATOGRAPHY FOR $\alpha$-MANGOSTIN ANALYSIS IN MANGOSTEEN PERICARP EXTRACT FOR ROUTINE ANALYSIS WITH PHOTODIODE ARRAY DETECTOR
}

\author{
Muchtaridi Muchtaridi*, Moses Prasetio, Nyi Mekar Saptarini \\ and Febrina Amelia Saputri
}

Department of Pharmaceutical Analysis and Medicinal Chemistry, Faculty of Pharmacy, Padjadjaran Universit, JL. Bandung-Sumedang KM-21, Jatinangor, West Java, Indonesia, 45363

*E-mail : muchtaridi@unpad.ac.id

\begin{abstract}
The analytical methods for the standardization of $\alpha$-mangostin are needed to set up a routine of a validated method for quality control of $\alpha$-mangostin from Garcinia mangostana L. using HPLC methods. This study was aimed to validate the analytical method of High-Performance Liquid Chromatography (HPLC) for $\alpha$-mangostin analysis with Photodiode Array (PDA). The analysis was conducted by HPLC with octadecyl silanol column, methanol and acetic acid $1 \%$ as a mobile phase and PDA detection at $243 \mathrm{~nm}$. The coefficient correlation of analytical method was was 0.9999 , the variation was less than $2 \%$, LOD was $0.671 \mathrm{ppm}$, and LOQ was $2.174 \mathrm{ppm}$. The level of $\alpha$-mangostin in mangosteen pericarp extract from Tasikmalaya was $8.56 \pm 0.003 \%$. The analytical method was met the validation criteria. The PDA sensitivity was $68.28 \%$ higher than UV-Vis detector.
\end{abstract}

Keywords: mangosteen, $\alpha$-Mangostin, validation, sensitivity, photodiode array.

(C) RASĀYAN. All rights reserved

\section{INTRODUCTION}

Mangosteen (Garcinia mangostana) has a dark red skin fruit with white flesh and sweet taste of fruit ${ }^{1}$. Mangosteen pericarp was used as an alternative treatment ${ }^{2}$, such as heart medications ${ }^{3}$, lowering the blood sugar $^{4}$, malaria medicines, anti-inflammatory agent ${ }^{5}$, antimicrobial, and antioxidants ${ }^{6}$. Xanthone is main seconder metabolite in mangosteen pericarps. $\alpha$-mangostin is major xanthone in mangosteen pericarp extracts $^{7}$. $\alpha$-mangostin has many pharmacological properties such as mosquitoes larvicide, anti-bacteria, antifungal ${ }^{8}$, anti-cancer ${ }^{9}$, antioxidant ${ }^{10}$, anti-tuberculosis ${ }^{11}$, and analgesic. ${ }^{12}$ It also has strong activity as anti-cancer. $\alpha$-mangostin $(10 \mu \mathrm{M})$ inhibited of HL60 (Human Promyelocytic) leukemia cell line in humans via apoptotic induction ${ }^{9}$. $\alpha$-mangostin in PC12 (Phaeochromocytoma) cells induces via mitochondrial pathways is induced $\mathrm{Ca}^{2+}$-ATPase-dependent apoptotic ${ }^{13}$. IC $\mathrm{I}_{50}$ values of $\alpha$-mangostin are almost equal to 5FU (5- Fluorouracil) in the DLD-1 SLJJ-1 cell model. ${ }^{14}$ Muchtaridi and Wijaya (2017) ${ }^{14}$ predict that $\alpha$ mangostin has new opportunities for effective cancer drug discovery.

In the previous study, analytical methods for the determination of $\alpha$-mangostin have been reported. ${ }^{15,16} \alpha$ Mangostin was analyzed by High-Performance Liquid Chromatography (HPLC) with methanol and 1\% acetic acid (95: 5) as mobile phase using UV-Vis as the detector. The limitations of this method were high values of the limit of detection and quantification, i.e. $2.123 \mathrm{ppm}$ and $7.072 \mathrm{ppm}$, respectively ${ }^{7}$.

In this study, we were developed the new analytical methods of $\alpha$-mangostin using the HPLC with Photodiode Array (PDA) as detector due to PDA has better sensitivity compared to UV-Vis. So, the aim of this study was to validate the analytical method of HPLC with PDA for $\alpha$-mangostin analysis.

Rasayan J. Chem., 11(3), 973-978(2018)

http://dx.doi.org/10.31788/RJC.2018.1132098

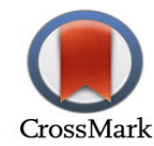


RASĀYAN J. Chem.

Vol. 11 | No. 3 | 973 - 978 | July - September | 2018

\section{Materials}

\section{EXPERIMENTAL}

The mangosteen pericarp from Tasikmalaya was macerated with $70 \%$ ethanol, then standardized according to parameters of General Standard Extracts of Plant Medicine by Indonesian Food and Drug Regulatory Agency. $\alpha$-mangostin standard (Chengdu Biopurify), methanol pro HPLC (Merck), acetonitrile (Merck), aquabidestillata (IPHA Laboratories) and 96\% acetic acid (Merck).

\section{General Procedure}

\section{Preparation of $\alpha$-Mangostin Standard Solution.}

A total of $10 \mathrm{mg}$ of $\alpha$-mangostin was dissolved in $100 \mathrm{ml}$ of methanol (100 ppm), and then created a variation of concentration in $10 \mathrm{ml}$ flask.

\section{Mobile Phase Preparation}

Methanol and 1\% acetic acid with a ratio of 95: 5 was degassed to remove air bubbles, then filtered with $0.45 \mu \mathrm{m}$ membrane filter, and sonicated for 10 minutes.

\section{HPLC Validation}

HPLC condition was Enduro C18G (diameter $4.6 \mathrm{~mm}$; length $25 \mathrm{~cm}$ ) as column and the flow rate was 1 $\mathrm{ml} / \mathrm{min}$. The validation methods consisted of linearity, accuration, precision, Limit of Detection (LOD), Limit of Quantification (LOQ), and specificity. Linearity was done to get calibration curve that fulfills the requirements. The calibration curve was obtained by measuring various concentration $(1.5,2.5,5,10,20$ and $40 \mathrm{ppm}$ ). Accuration was done by measuring the same concentration. Precision was done by measuring one concentration with six times repetition a day for intraday precision and three days in a row for interday precision. LOD and LOQ were done to determine the lowest concentration which can be detected or quantified. Specificity was done to determine if the method could distinguish the sample from the other component inside the matrix.

\section{Analysis of $\alpha$-Mangostin in Mangosteen Pericarp Extract}

The mangosteen pericarp extract solution $(20 \mu \mathrm{l})$ was injected to HPLC. The concentration of $\alpha$-mangostin was calculated by measuring the area under the curve to the linear regression equation.

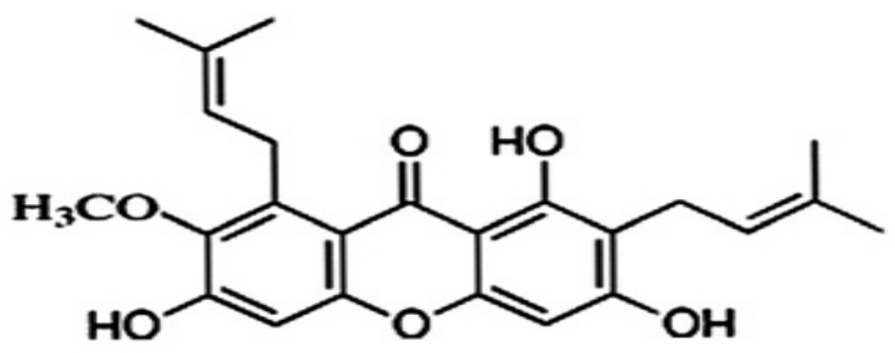

Fig.-1

\section{RESULTS AND DISCUSSION}

$\alpha$-Mangostin absorbance was measured at the maximum wavelength to increase the analysis sensitivity ${ }^{16,-}$ 18. There were three peaks appear on the chromatogram. The maximum wavelength of $\alpha$-mangostin was $243 \mathrm{~nm}$ (Fig.-2). The first peak was located in the UV cut-off, which provided a solvent uptake. So, it can't be used for wavelength selection ${ }^{19}$. The third peak has a lower absorbance compared to the second peak. This result was different from the previous study, i.e $246 \mathrm{~nm}^{7}$. The maximum wavelength shifts were caused by several factors, such as a detector, solvents, and quality of sample preparation. The HPLC system was met the suitability criteria. Suitability system was needed to see whether the method that we use has fulfilled the requirements. If the method that we use has fulfilled the requirements, then we could use the method. Suitability system is also needed to see the reproducibility of the method ${ }^{20}$. 
RASĀYAN J. Chem.

Vol. 11 | No. 3 |973 - 978 | July - September | 2018

Table-1: The HPLC suitability

\begin{tabular}{l|l|l}
\hline Parameter & Requirements & Results \\
\hline Tailing Factor & $\begin{array}{l}\text { Symmetrical chromatogram } \\
\text { pattern }\end{array}$ & $\begin{array}{l}\text { Symmetrical chromatogram } \\
\text { pattern }\end{array}$ \\
& $-\quad$ Asymmetric factor 1-1.2 & $-\quad$ Symmetric factor = 1 \\
& No tailing & \\
\hline Plate Number & $>2500$ & 12257,58 \\
\hline HETP & Low value & 0.0239 \\
\hline Capacity Factor & $1-15$ & 1.417 \\
\hline
\end{tabular}

Table-2: The Validation Method

\begin{tabular}{l|l|l}
\hline Parameter & $\begin{array}{l}\text { Requirements } \\
\text { (USP ed 32, 2007) }\end{array}$ & Results \\
\hline Linearity & $\mathrm{R}^{2}>0.99$ & $\mathrm{R}^{2}=0.9999$ \\
\hline Accuracy & Recovery $80-120 \%$ & $95-110 \%$ \\
\hline Precision & $\mathrm{KV}<2 \%$ & $1.6-1.9 \%$ \\
\hline Limit of Detection & & $0.673 \mathrm{ppm}$ \\
\hline Limit of Quantification & & $2.179 \mathrm{ppm}$ \\
\hline Specificity & $\mathrm{KV}<2 \%$ & $0.1-1.2 \%$ \\
\hline
\end{tabular}

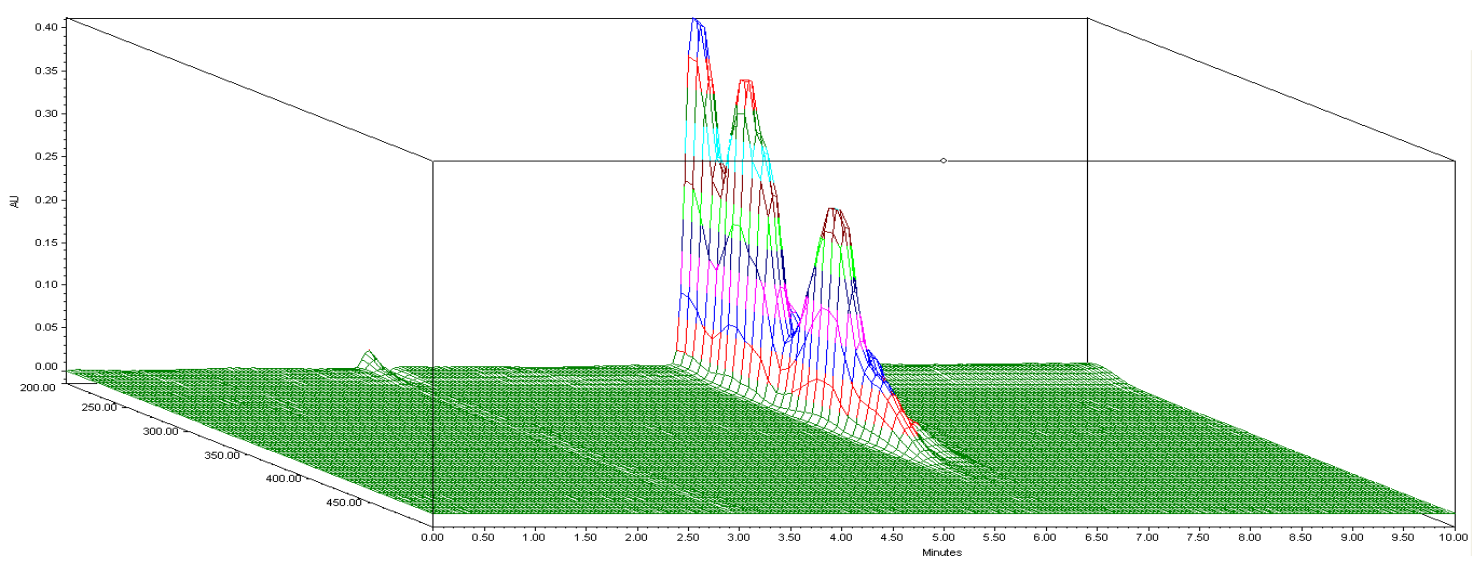

Fig.-2: Wavelength determination of $\alpha$-mangostin at $200-400 \mathrm{~nm}$.

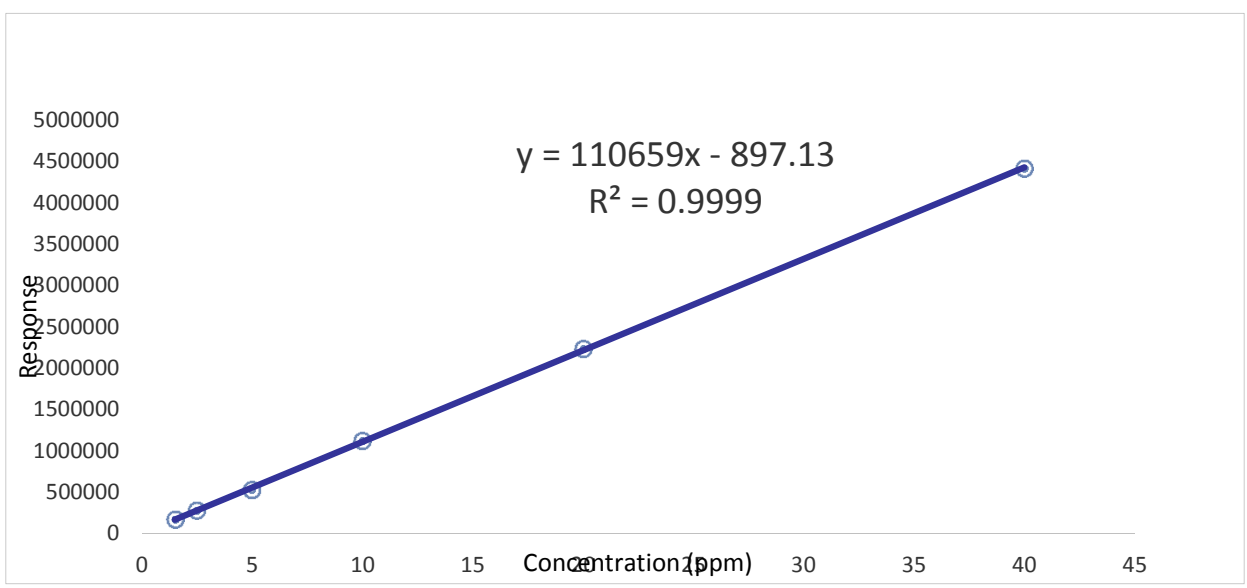

Fig.-3: Calibration curve of $\alpha$-mangostin standard 
The value of LOD which obtained using PDA $(0.673 \mathrm{ppm})$ was lower compared with the UV detector $(2.122 \mathrm{ppm})^{7}$. There was increasing sensitivity, i.e. $68.28 \%$. The PDA sensitivity caused by the high intensity of the signal transferred from the diode to the other diode, or in other words when a signal is transmitted between the diode, multiplication signal is happened due to when arriving at the detector, the intensity of the detected signal becomes stronger. PDA also has a high signal to noise ratio $(\mathrm{S} / \mathrm{N})$, which means that the sensitivity of the PDA detector is high ${ }^{20}$.

The ratio between the concentration and the area under the curve was calculated (Fig.-3). In Fig.-5., the 3D chromatogram showed the comparison of the retention time, wavelength and the area under the peak (Fig.5). The 2D chromatogram usually used to see the response of compound of the analyte, further, it can be used to analyze the concentration of the compound.

The 3D chromatogram pattern is also the same. But the difference is the 3D chromatogram pattern usually used to see the peak purity of a compound by comparing the peak of the compound and the peak of samples. The concentration of $\alpha$-mangostin in mangosteen pericarp extract from Tasikmalaya was $8.56 \pm 0.003 \%$. This value was lower than previous study ${ }^{7}$.

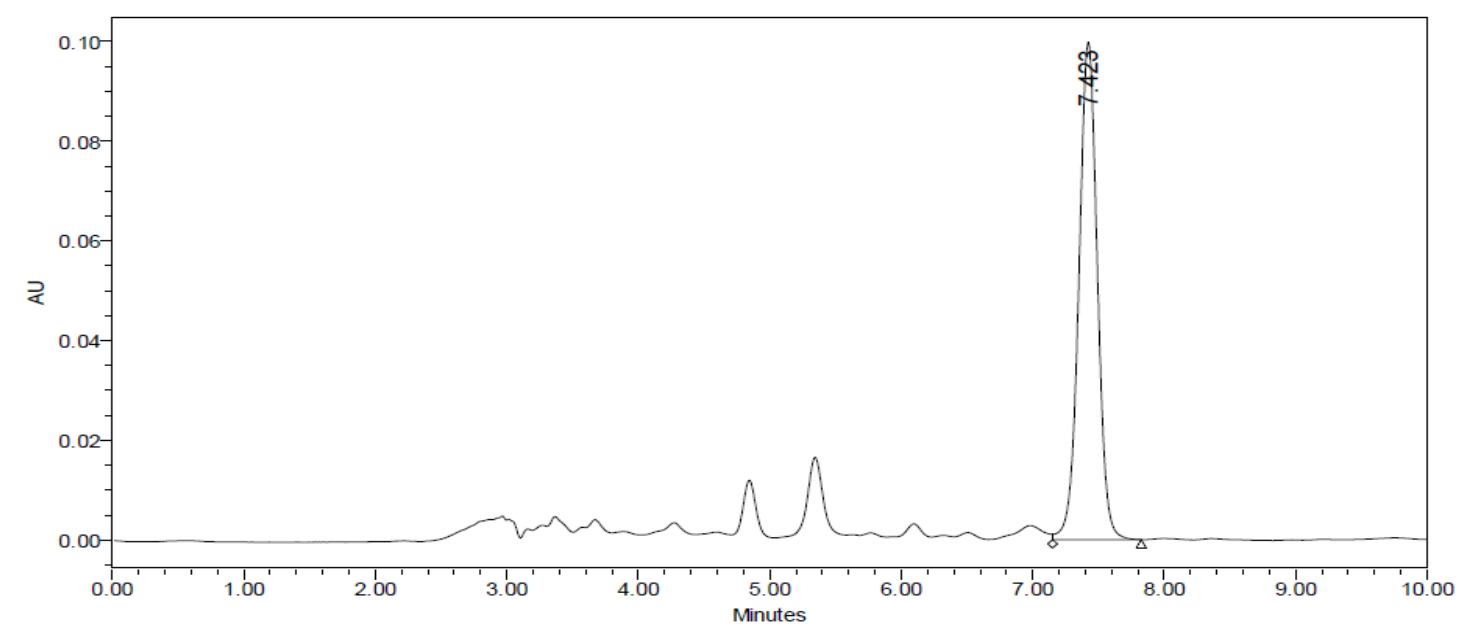

Fig.-4: The 2D Chromatogram Pattern of Extract

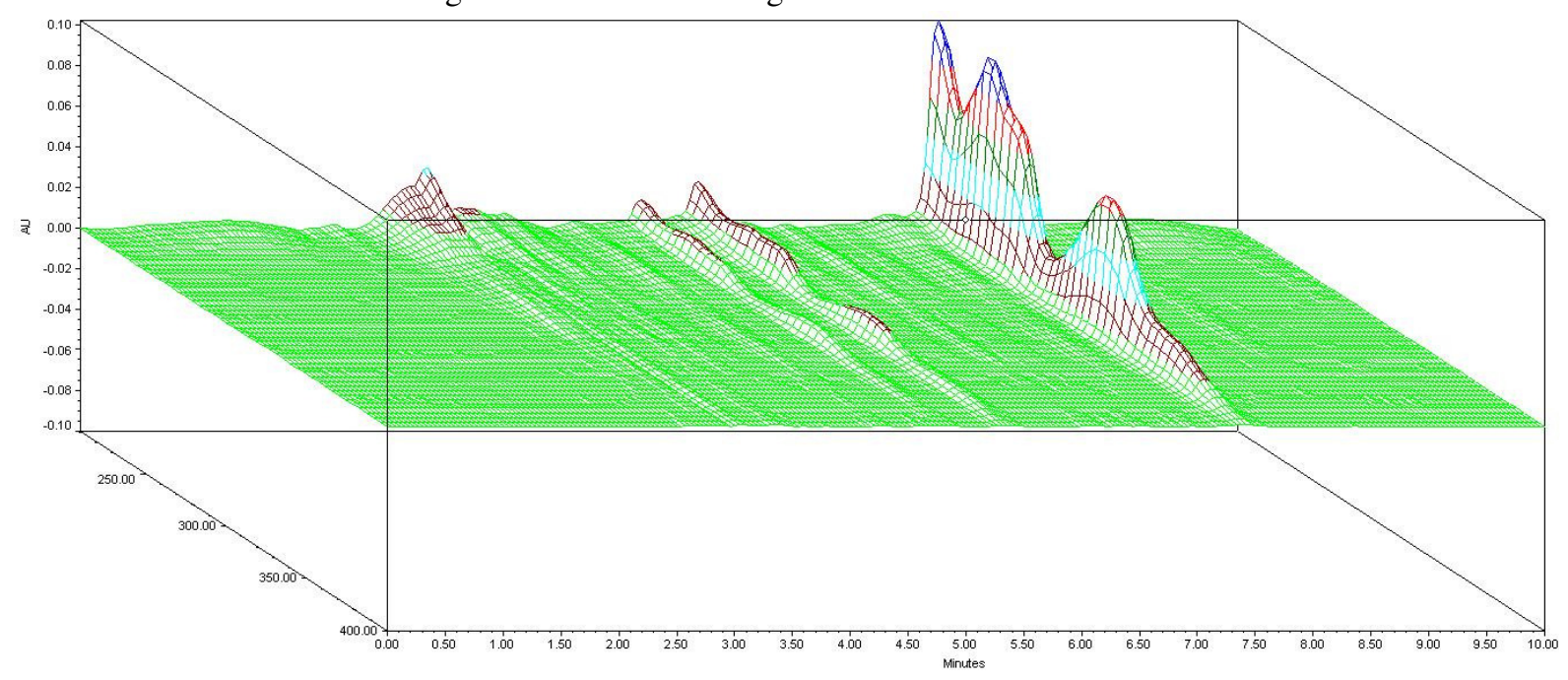

Fig.-5: The 3D Chromatogram Pattern of Extract

The concentration differences of $\alpha$-mangostin in mangosteen pericarp extracts were affected by PDA higher sensitivity than UV detector. More sensitive testing methods cause analysis becomes more sensitive to filter or differentiating compounds being analyzed. Therefore, using a PDA detector will produce peak purity 
that is good, which means the peak measured compounds derived from $\alpha$-mangostin with low levels of impurities.

In contrast to the use of UV-Vis detectors are less sensitive. This means the possibility of accumulation of absorption produced by other compounds in the sample when the measurement is made greater when compared with the use of the PDA detector. If accumulated, then it will affect the absorption produced that will increase the response on the chromatogram. Therefore, the use of HPLC method with UV-Vis detector will generate greater levels when compared to PDA detector. The difference of $\alpha$-mangostin compound in mangosteen peel extract is influenced by various factors, namely planting and harvesting time, sample preparation factor and extract storage factor ${ }^{21}$. Planting and harvesting times affect $\alpha$-mangostin levels in mangosteen peel extracts. Appropriate rainfall, humidity, temperature and cultivation time and harvest will increase the levels and quality of $\alpha$-mangostin in the skin of the mangosteen ${ }^{22}$. Another factor is the storage of extracts. Extracts stored in sun-exposed conditions and with high temperatures tend to decrease in levels so that appropriate storage of extracts is critical in influencing the levels of the samples analyzed.

\section{CONCLUSION}

The analytical method was met the validation criteria. The PDA sensitivity was $68.28 \%$ higher than UV$\mathrm{V}$ is detector. The $\alpha$-mangostin concentration in mangosteen pericarp extract from Tasikmalaya was $8.56 \pm$ $0.003 \%$.

\section{ACKNOWLEDGMENT}

The Directorate General of Higher Education of The Ministry of Research and Technology of Indonesia supported this study through PUPT Grants 2018.

\section{REFERENCES}

1. P. Khumsupan, P. Sithisan, M. Chittima and W. J. Gritsanapan, Chem. Bio. Phy. Sci. Sec., 4(4), 3406 (2014).

2. N. Yoswathana and M. N. Eshtiaghi, Inter. J. Chem. Eng. App., 6(2), 115 (2015), DOI: 10.7763/IJCEA.2015.V6.463.

3. D. J. Jiang, Cardio. Drug Rev., 22 (2), 91 (2004), DOI: 10.1111/j.1527-3466.2004.tb00133.x.

4. M. Muchtaridi and C. Wijaya, Asian J. Pharm. Clin. Res., 10 (12), 440 (2017), DOI: 10.22159/ajpcr.2017.v10i12.20812.

5. L.G..Chen, Yang, L.L. and Wang, C.C., Food Chem. Toxicol., 46, 688 (2000), DOI: 10.1016/j.fct.2007.09.096.

6. T. M. Chomnawang, S.V. Surassmo, and W. Gritnasapan, J. Ethnopharmacol., 101, 330 (2005), DOI: 10.1016/j.jep.2005.04.038.

7. El-Seedi, H.R., El-Ghorab, D.M., El-Barbary, M.A., Zayed, M.F., Goransson, U., Larsson, S. and Verpoorte, R., Current Medicinal Chemistry., 16, 2581 (2009), DOI: 10.2174/092986709788682056.

8. M. Muchtaridi, D. Suryani, WA. Qosim, NM. Saptarini, Int. J. Pharm. Pharm. Sci., 8 (8), 232 (2016).

9. S. Purwantiningsih, S. Arya, A. Ilmiawati and B. Arifin., Rasayan J. Chem., 10 (3), 701 (2017), DOI: 10.7324/RJC.2017.1031766.

10. K. Matsumoto, Y. Akao., K. Ohguchi, T. Ito, T. Tanaka, M. Iinuma, Bioorg. Med. Chem., 13, 6064 (2005), DOI: 10.1016/j.bmc.2005.06.065

11. S P. Suvarnakuta, C. Chaweerungrat, S. Devahastin, Food Chem., 1, 240 (2011).

12. P. Arunrattiyakorn, S. Suksamrarn, N. Suwannasai, H. Kanzaki, Phytochem, 72, 730 (2011), DOI: 10.1016/j.phytochem.2011.02.007

13. J. Cui, W. Hu, Z. Cai, Y. Liu, S. Li, Pharmacol. Biochem. Behav, 95, 166 (2010), DOI: 10.1016/j.pbb.2009.12.021

14. A.H. Sato. Fujiwara, H. Oku, K. Ishiguro, Y. Ohizumi, J. Pharmacol Sci., 95, 33 (2014).

15. M. Muchtaridi, N.A. Puteri, T.Milanda, I. Musfiroh, J. Appl Pharmaceu Sci., 7(10), 125-130 (2017), DOI: $10.7324 / J A P S .2017 .71018$

16. Y. Akao, Y. Nakagawa, M. Iinuma, Y. Nozawa., Int. J. Mol. Sci., 9(3), 355 (2008), DOI: 10.3390/ijms9030355 
RASĀYAN $J$. Chem.

Vol. 11 | No. 3 |973 - 978 | July - September | 2018

17. S. Kongkiatpaiboon, R. Vongsak, S. Machana, T. Weerakul, C. Pattarapanich, J. King Saud University Sci., 28, 131 (2008),, DOI: 10.1016/j.jksus.2015.06.007

18. A.F.A. Aisha, M.A.S. Khalid, I. Zhari, and M. Amin, BMC Compl Alter Med, 12, 104 (2012), DOI: 10.1186/1472-6882-12-104

19. Kaye and Laby, 2005. http://www.kayelaby.npl.co.uk/chemistry/

20. W. Pothitirat, and W. Gritsanapan, J. Health Res. 22(4),161 (2008).

21. A. Hasanah, I. Musfiroh, and M. Muchtaridi, Psychochemical Analysis Fundamental in Pharmaceutical (in Indonesia), Gudang Buku, Jogjakarta, 2016.

22. L.R. Snyder, Practical HPLC Method Development, Second Edition, John Willey \& Sons inc, New York, 1997.

[RJC-2098/2018] 